日本人類遺伝学会第 27 回大会記事 (1982)

\title{
Proceedings of the 27th Annual Meeting of the Japan Society of Human Genetics, 1982
}

\author{
会場 東京都千代田区大手町 1-8-3 農劦ビル \\ 会 期 昭和 57 年 11 月 9 日，10日，11日 \\ 大会会長 松永 英 (国立遺伝学研究所部長) \\ 大会幹事岡島道夫, 外村 晶, 笹月健彦 (東京医科歯科大学教授) \\ 発 表 特别講演 \\ 1）松永 英（国立遗伝研・人類遗伝）：ヒトの発癌機構研究そデルとしての綁膜芽紐 \\ 胞腫 \\ 2）佐々木正夫（京大・放射線生物研）：遺伝性発癌素因と染色体突然変異 \\ シンポシウム
}

遺伝分析技術の進歩と人類遗伝学 司会 荻田善一（富山医科菜科大）

第 1 日（11月 9 日）

松永大会会長の開会の辞に引き続き，年前中に A, B 2 会場で一般講演 32 題の発表があった. 午後は 2 題の特別講演が㐫り,ついで 2 会場で一般講演 24 題が発表された. その後，C会場で 14 題のポスター・セッションによる発表がすった。

第 2 日 (11月 10 日)

午前中, 2 会場で 34 題の一般講演が屴った. 个後は総会議事に引き続いて, シンポジウムと 14 題のポスターセッションでの発表が㐫った，発表終了後，琹親会が開催さ礼た。

第 3 日 (11月 11 日)

午前中の一般講演 31 題の発表と大会会長の閉会の辞をもって, 全口程を終了した。

\section{評議 員会}

日 時: 昭和 57 年 11 月 8 日 $17: 00-19: 00$

場 所 : 学士会館 (一ツ橋)

I 、 報告事項

1. 物故名誉会員㐨よび会員の報告

2. 庶務報告 (黒木幹事) 会員の異動状況，本年 2 回の理事会開催（9月11日，11月８日）について報告があった。

3. 会計報告 (池内幹事)

1）昭和 56 年度会計報告がなされ，それに対する松永理事による同会計監查報告が苟った。

2）昭和 57 年度会計中間報告がなされた。

4. 編集報告 (外村委員長)

論文の投稿，受理状況等について報告された。

5. 委員会報告

Vol. 28, No. 2, 1983 
1) 学会賞選考委員会報告 (井上会長)

本年度の授賞注該当者なしと決定された旨の報告があった（人遗誌 27 巻 1 号，53 頁参照)

2）人類遣伝学用語委員会報告（外村委員）

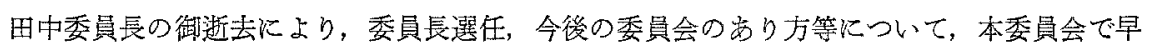
急に検討するとの報告があった。

6. 58 年度大会準備状沉報告（松本次期大会長）

昭和 58 年 11 月 9 日 11 日，宝塚市，宝榢ホテルで開催予定との報告があった。

7. 理事担当事項等報告

国際人類遺云学会常置委員会 (井上会長)：1986 年開催予定の第 7 回国際人類遺伝学会議の開 催地は西べルリンに決定した旨の報告があった。

文部省科研費関係（三輪理事），学術会議関連（井上会長），日本医学会評議員会（三輸理事）

より，旮れ艺れの報告がなされた。

8. その他

遺伝相談ネットワーク委員会報告書が会長に提出された。この報告書に会長の前文をつけて，

人遺誌渴載し, 会員に意見を問らことになった。本報告書は今後, 本学会としての統一的な遺 伝相談を考觉る際の筫料となるものである。

II. 協議毫項

1. 会長の任期汇関さる件

会長の任期問題が討議され，会則第十一条の改正案文（下記）が示され了承された.

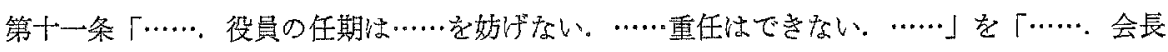

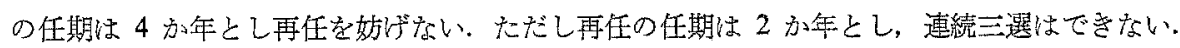
理事の……重任はできない。評議員, 幹事の任期は 2 か年とし重任を妨げない．….」と改める.

2. 59 年度大会開催地。大会長の件

荻田善一教授（富山医科薬科大）を大会長に，富山市で開催されることが討議の上，了秀された.

3. 名誉会員として N. E. Morton 氏（米国ハワイ大学教授）が満場一致で推蔗された。

4. 故田中克己名誉会員の御遗族よりの本学会への管付金の使途见ついて討議され，故田中名誉会 員の御遺志に沿う目的使用する線が了承された。

\section{総会議事}

I 、 報告毫項

1) 庶務報告 (黑木幹事)

会員の異動状沉，理事会の開催について報告が㐫った。

会員の異勫状況（昭和 57 年 4 月 1 日現在）

\begin{tabular}{|c|c|c|c|c|c|c|c|c|}
\hline & & & & & 現在数 & 入 会 & 退 会 & 增 減 \\
\hline \multirow[t]{2}{*}{ 普 } & 通 会 & 員 & & 内 & 829 & 59 & 57 & +2 \\
\hline & & & 国 & 外 & 19 & 4 & 0 & +4 \\
\hline & 会 & 員 & 国 & 肉 & 20 & 1 & 1 & 0 \\
\hline & & & 国 & 外 & 10 & 2 & 1 & +1 \\
\hline 機 & 関 会 & 員 & & & 94 & 1 & 0 & +1 \\
\hline & 持 会 & 員 & & & 1 & 1 & 0 & +1 \\
\hline & 計 & & & & 973 & 68 & 59 & +9 \\
\hline
\end{tabular}


2）会計報告（池内幹囊）

昭和 56 年度会計報告ならびに昭和 57 年度会計中間報告がなされた。

昭和 56 年度会計報告

\begin{tabular}{|c|c|c|c|c|}
\hline 収 & 入 & \multicolumn{3}{|c|}{ 支 } \\
\hline 前年度繰越金 & $3,698,618 म$ & 雑 誌 刊 行費 & $2,934,742$ 円 & 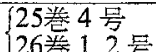 \\
\hline 会費 & $3,757,129$ & 雑誌発送費 & 183,771 & \\
\hline 雑誌壳上代 & 541,380 & 雑誌編集 葿 & 10,000 & \\
\hline 論文掲戴料 & 368,010 & 事 務 費 & 616,553 & \\
\hline 文部省科研費 & $1,220,000$ & 会員名簿作成蒷 & 286,000 & \\
\hline 医師会助成金 & 100,000 & 大会袺助金 & 600,000 & \\
\hline 広告揭載料 & 138,250 & I G F 会費 & 41,640 & \\
\hline 預 金 利子 & 98,635 & 理事会旅書 & 105,000 & \\
\hline \multirow{3}{*}{ 計 } & \multirow{3}{*}{$9,922,022$ 円 } & 人件費 & 480,000 & \\
\hline & & 次年度繰越金 & $4,664,316$ & \\
\hline & & 計 & $9,922,022$ 円 & \\
\hline
\end{tabular}

炤和 57 年度中間報告 $(57.1 .1 \sim 10.25)$

\begin{tabular}{|c|c|c|c|c|}
\hline 収 & 入 & & 支 & \\
\hline 前年度繰越金 & $4,664,316$ 円 & 雑誌刊行實 & $4,140,395$ 円 & $\left\{\begin{array}{l}26 \text { 巻 } 3,4 \text { 号 } \\
27 \text { 拳 } 1,2 \text { 号 }\end{array}\right.$ \\
\hline 会費 & $2,656,950$ & 雑誌発送費 & 338,583 & \\
\hline 雑誌売上代 & 442,630 & 集誌螎箱費 & 25,500 & \\
\hline 論文揭戴料 & 259,749 & 事 務 䟺 & 462,445 & \\
\hline 文部省科研蒷 & $(1,280,000)$ & 理事会旅蒷 & 97,900 & \\
\hline 医師会助成金 & 100,000 & 人件 費 & 360,000 & \\
\hline 預 金 利 子 & 50,021 & \multirow[t]{2}{*}{ 計 } & \multirow[t]{2}{*}{$5,424,823 円$} & \\
\hline 誩 & $9,453,666$ 円 & & & \\
\hline
\end{tabular}

3）編集報告（外村委員長）

論文の投稿，受理状況などが報告された。

4) 炤和 58 年度大会の準備状況が報告された（淞本次期大会長）.

5) 委員会報告

学会賞選考委員会 (井上会長)，人類遺伝学用語委員会 (外村委員)より竍告がなされた。 打，用語委員会委員長の選任は理事会に一任された。

6）理事坦当事項等報告

国際人類遣公学会営置委員会 (井上会長) より，1986 年の第 7 回国際人類遺伝学会議は西へ ルリンで開催される旨の報告があった。

文部省科研㶳関係 (三輪理事)，学術会議関連（井上会長），日本医学会評議員会（三輸理事） よりそれぞれ報告がなされた。 
II. 協議事項

1）会長の任期にかかわる会則第十一条の改正案が提出され，原案ざ㧍り了承された（評議員会記 録参照).

2）昭和 59 年度大会は富山市で，荻田善一教授（富山医科薬科大）を大会長として開催する案が 示され，了承光れた。

3） N. E. Morton 氏（ハワイ大学教授）が 40 人目の名誉会員として推薦され，満場一致で了承 己秃た。

4）その他，故田中名誉会員の御遗族よりの答付金の使梌，用語委員会委員長等に関して協議がな された。

理 事 会

日 時: 昭和 57 年 11 月 8 日 $15: 00 \sim 17: 00$

璂 所 : 学士会館 (一ツ橋)

出席者: 井上会長, 松永, 柳㖽, 中島, 三輸, 佐冬木, 䇼月各理事, 外村委員長, 松本次期大会 長, 激内, 黒木各幹事

1) 庶務関係では会員の異動状況が報告された。

2）会計関係では 56 年度会計報告と同監查報告乱よび 57 年度会計中間報告があった.

3）編集関係では論文投稿が順調である旨の報告があった。

4）昭和 58 年度大会準備状沉報告, 蛒よび昭和 59 年度大会開催地と大会長案が示された。

5）名誉会員として Morton 氏が推薦された（総会議事記録参照）.

6） 1986 年の国際人類遺伝学会議注西ベリンで開催されることになった旨の報告があった。

7）前回理事会に引き続き会長の任期に関する討議がなされ，会則の一部改正案が示された.

8）人類遺云学用語委員会委員長選任の件，遗伝相談ネットローク委員会報告書の取り扱いなどに ついての討議があった(評議員会記録参照).

9）故田中名誉会員の御遗族よりの寄付金の使途について検期された。

（庶務幹事 黑木良和） 